\title{
Phoma Canker of Pigeonpeas in Puerto Rico
}

\author{
Luis A. Alvarez García
}

INTRODUCTION

Pigeonpea production in Puerto Rico is quite important in the hilly areas in the vicinities of Peñuelas, Adjuntas, Villalba, and Jayuya. The types of soils and climatic conditions are not particularly adapted for the economical cultivation of many other farm crops.

Remunerative returns are obtained through the marketing of green peas, dry peas, and canned peas. According to a recent report $(1)^{2} 75$ percent of the pigeonpeas produced in Puerto Rico are marketed locally and the surplus is shipped to New York. The pigeonpea plants grow perennially in Puerto Rico and a new crop is harvested every year. The bulk of the harvest occurs during the December to February period.

The variety Kaki comprises 55 percent of the area planted and 17 percent of the land is sown with other varieties. About 44 percent of the total area under cultivation is being sown with mixed-variety seed. Considering the farm value of the pigeonpea crop reported in 1954-55, amounting to $\$ 1,050,000$, it is important to study the diseases impairing this agricultural crop and find practical methods of control.

\section{EPIDEMIC OF PHOMA CANKER}

Early in February of 1954 a serious epidemic of phoma canker was observed causing damage to the pigeonpea crop (Cajan cajan (L.) Millsp.) grown commercially in the vicinity of Penuelas, P. R. The lesions appeared on stems and branches, first as minute blotchy spots of irregular shape and varying from a mere speck to swollen cankerous areas 2 or $3 \mathrm{~cm}$. in length. The lesions entered the bark and spread lengthwise. Some of them girdled the stem and branches causing the death of the parts of the plant above.

Seedlings were attacked early with sootylike spots and, if girdled, they succumbed to the infection. Abundant pycnidia were found on the young sootylike spots. Conidia oozed from these pycnidia when they became wet. The conidia progressed down the stems and branches causing lineal infections. The stems and branches had a striped appearance.

The lesions generally enlarged longitudinally, swelling and breaking open the bark and becoming cankerous with age. The cankerous areas split characteristically showing a rough, ruggose appearance. On the stems, the cankers were more common at the collar area.

' Phytopathologist, Department of Phytopathology, Agricultural Experiment Station, University of Puerto Rico, Río Piedras, P. R.

2 Italic numbers in parentheses refer to Literature Cited, p. 30. 


\section{IRESULTS OF S'TUDY}

\section{The Causal Agent of Disease}

The disease is caused by a species of Phoma characterized by the formation of papillate pyenidia of variable size. Isolations were made from diseased spots and the fungus grown on agar. In culture, pycnidia are formed singly or in aggregates in a sort of stroma. The conidia are hyaline, obtuse, and measured in length from 3 to $6.4 \mu$. with an average of $4 \times 1.5$. $\mu$. No

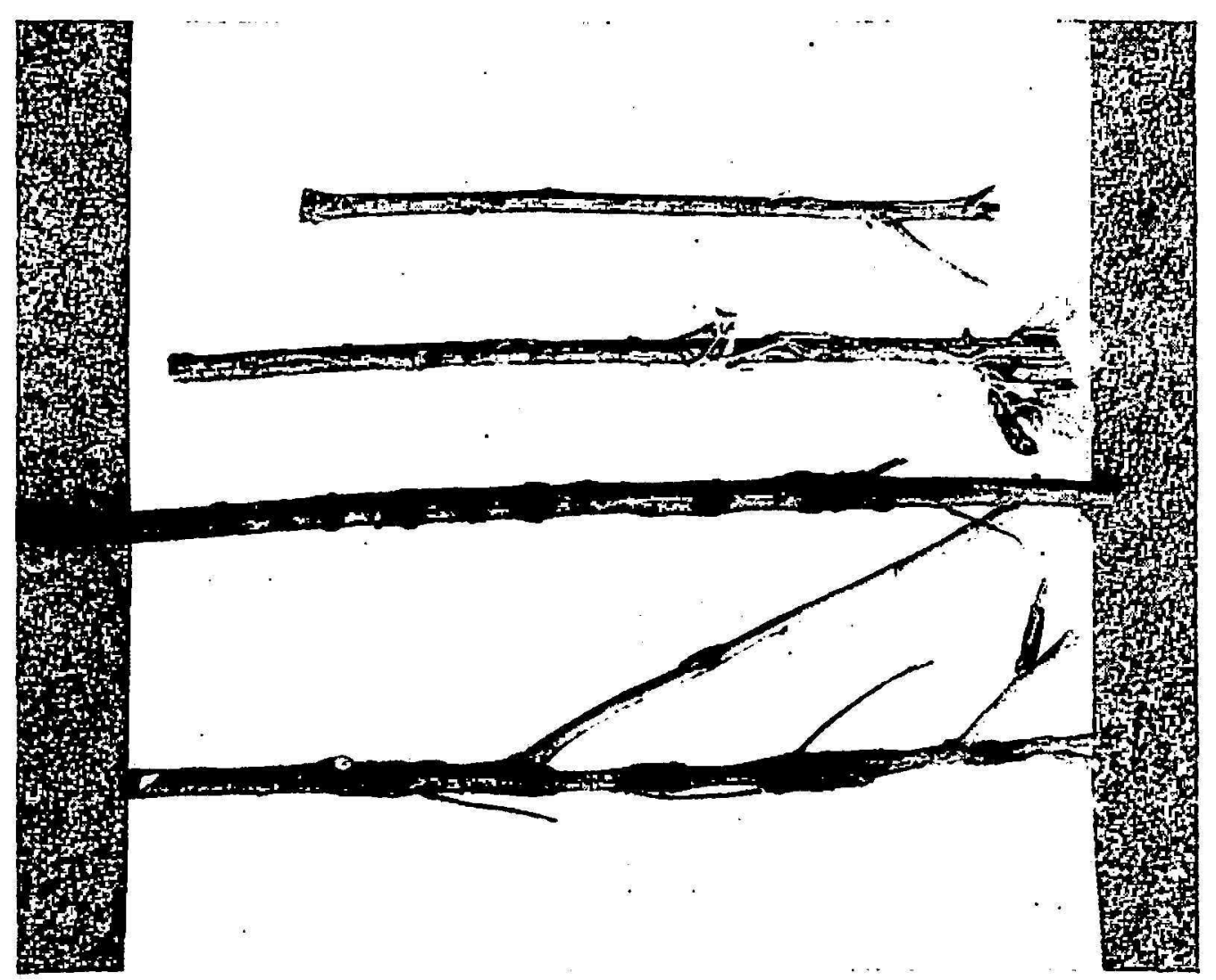

FIG. 1.-Characteristic cankers produced on Kaki pigeonpen plants hy inoculation.

perfect stage of the fungus was found in the lesions of stem and branch nor in culture plates. Pycnidia were also found on the pods. Conidial infections and contamination were evident in some of the seed peas.

\section{Experimental Work}

Fxperiments in the laboratory and greenhouse showed that young pigeonpea plants (Kaki variety) when inoculated by prickling with a needle using drops of a water suspension of conidia obtained from pure culture, or by spraying the young seedlings with suspensions of conidia, showed necrotic lesions a week later. The characteristic cankers obtained from our inoculations are seen in figure 1. 
In our inoculation studies under greenhouse conditions it was found that the Phoma sp. isolated was capable of inducing the carbonaceous appearance of the cankers produced without presence of other fungi. Further studies on the biology and ecology of the organism seem advisable.

\section{DISCUSSION}

R. Leach and J. Wright (2) reported a collar and stem canker of pigeonpeas caused by a species of Physalospora: a Phoma and a Macrophoma pycnidia were shown to be the imperfect form of this fungus. These authors also found a Diplodia which they thought was responsible for the carbonaceous appearance of the cankers induced by the Macrophoma.

\section{SUMMARY}

An epidemic of phoma canker was observed in February 1954, causing considerable damage to the pigeonpea crop, a rather important one in Puerto Rico. This paper reports a study of the causal agent, a species of Phoma characterized by the formation of papillate pycnidia of variable size. The disease could be produced in healthy pigeonpea plants by inoculation or by spraying with a water suspension of conidia obtained from a pure culture. Further study is advisable.

\section{RESUMEN}

En febrero de 1954 se observó una epidemia de Phoma gangrenosa que causó mucho daño a la cosecha de gandures, cultivo de gran importancia en P'uerto Rico. Este estudio informa sobre el agente cuusal de la epidemia, que es una especie indeterminada de Phoma la cual se caracteriza por la formación de picnidios papilados de distintos tamaños. La enfermedad pudo trasmitirse a plantas saludables de gandures, por medio de la inoculación o mediante las aspersiones con suspensiones de conidios obtenidos de un cultivo puro. Se recomienda la continuación de los estudios sobre esta enfermedad.

\section{LITERATURE CITED}

1. Iloréns, Antonio A., Oliveras, José A., Producción y Mercadeo del Gandur en Puerto Rico, List. Lxp. Agr., Bol. 138, Marzo 1957.

2. Leach, R., and Wright, J., Collar and Stem Canker (Callanus Indicus) of Pigeonpea, Caused by a Species of Physalospora, Mem. Imp. Col. Trop. Agr. (Mycol. Ser.) i, 12 pp., 4 pl., 1930. 